\title{
Szabad gyökök és a máj ischaemiás-reperfúziós károsodása
}

\author{
Szijártó Attila dr. \\ Semmelweis Egyetem, Általános Orvostudományi Kar, I. Sebészeti Klinika, Budapest
}

\begin{abstract}
Az ischaemiás-reperfúziós károsodás kiemelkedő jelentősége számos szerv és klinikai szituáció esetén jól bizonyított. A posztoperatív komplikációk prevalenciáját, a célszerv sérülését és a szisztémás szövődmények előfordulását jelentősen meghatározó károsodás mediálásában központi szerep jut a szabad gyököknek. A szabadgyök-stresszre kimondottan érzékeny máj anatómiailag és patofiziológiailag speciális ischaemiás-reperfúziós károsodása májsebészeti szempontból kulcsfontosságú. A reperfúziós károsodás mérséklésére számos kondicionáló eljárás (adaptív technikák, kémiai vegyületek) ismert. Jelen összefoglaló célja az ischaemiás-reperfúziós károsodás mérséklésére irányuló technikák áttekintése a szerző kutatócsoportjának eddigi munkássága (ischaemiás prekondicionálás, -perkondicionálás, glutaminszupplementáció, adenozin-, inozin-, levosimendan-, poli-ADP-ribóz polimerázgátlás szerepe) alapján, különös tekintettel a máj ischaemiás-reperfúziós károsodására, valamint a szabad gyökök abban betöltött patofiziológiai szerepére. Orv. Hetil., 2015, 156(47), 1904-1907.
\end{abstract}

Kulcsszavak: ischaemiás-reperfúziós károsodás, máj, szabad gyök, ischaemiás prekondicionálás

\section{Free radicals and hepatic ischemia-reperfusion}

The critical importance of the ischemic-reperfusive injury is well documented with regards to numerous organs and clinical conditions. Oxygen free radicals play a central role in the mediation of the injury, which dominantly influences the prevalence of postoperative complications, (long term) organ damage, and the potential manifestation of systemic reactions. The both anatomically and pathophysiologically unique ischemic-reperfusive injury of the liver, which is expressively vulnerable to free radicals, is of utmost importance in liver surgery. Several techniques (adaptive maneuvers, chemical agents) are known to ameliorate the reperfusive injury. Based on the prior research of the workgroup of the author, the aim of the current article is to overview the set of measures capable of attenuating ischemic-reperfusive injury (ischemic preconditioning, -perconditioning, administration of adenosine, -inosine, -levosimendan, and -poly-ADP-ribose-polymerase inhibitor), with special attention to the ischemic-reperfusive injury of the liver, as well as the special pathophysiological role of free radicals in mediating hepatic damage.

Keywords: ischemia-reperfusion injury, liver, free radicals, ischemic preconditioning

Szijártó, $A$. [Free radicals and hepatic ischemia-reperfusion]. Orv. Hetil., 2015, 156(47), 1904-1907.

(Beérkezett: 2015. augusztus 18.; elfogadva: 2015. szeptember 23.)

\section{Rövidítések}

ADP = adenozin-difoszfát; ALP = alkalikus foszfatáz; ALT = alanin-aminotranszferáz; $\mathrm{AMP}=$ adenozin-monofoszfát; ATP $=$ adenozin-triszfoszfát; CARS = compensatory anti-inflammatory response syndrome; $\mathrm{CX}=$ (circumflex artery) bal szívkoszorúér körbefutó ága; DAMP = danger-associated molecular pattern; DNS = dezoxiribonukleinsav; GSH = glutation redukált forma; $\mathrm{I}-\mathrm{R}=$ ischaemia-reperfúzió; ic. = intracelluláris; IFN- $\gamma=$ interferon- $\gamma ;$ IL- $1 \beta=$ interleukin- $1 \beta$; IL-6 = interleukin-6; iNOS = indukálható nitrogén-monoxid-szintáz; $\mathrm{K}_{\text {ATP }}^{+}=$ ATP-szenzitív $\mathrm{K}^{+}$-csatorna; $\mathrm{LAD}=$ (left anterior descendent coronary artery) bal szívkoszorúér elülső leszálló ága; $\mathrm{LDH}=$ laktát-dehidrogenáz; NADPH = nicotinamid adenin dinucleotid foszfát redukált formája; NF- $\kappa \mathrm{B}=$ nuclear factor kappa-B; MODS $/ \mathrm{MOF}=$ (multiorgan dysfunction syndrome/failure) többszervi elégtelenség; $\mathrm{mPTP}=$ mitochondrial permeability transition pore; $\mathrm{NO}=$ nitrogén-monoxid; PARP = poli-ADPribóz polimeráz; $\mathrm{PKC}=$ proteinkináz $\mathrm{C} ; \mathrm{RISK}=$ reperfusion injury salvage kinase; ROS $=$ (reactive oxygen species) oxigénszabadgyökök; SAFE = survival activating factor enhancement; seBi. = szérumbilirubin-koncentráció; SIRS = systemic inflammatory response syndrome; TLR $=$ Toll-like receptor; TNF- $\alpha=$ tumour necrosis factor-alpha; TUNEL = terminal deoxynucleotidyl transferase dUTP nick end labeling 
A különböző szervek ischaemiás-reperfúziós (I-R) károsodása napjainkban is a sebészeti kutatások élvonalába tartozik. Az akut verőér-elzáródások, szervtranszplantáció, vénás elzáródások, illetve nem okkluzív kórképek (redisztribúció, sokk, dialízis) az érintett szerv ischaemiás károsodását idézik elő, amelyet az elkerülhetetlenül szükséges reperfúzió tovább súlyosbít. A folyamat alatt képződő oxigén-szabadgyökök (reactive oxygen species - ROS) jelentős szerepet játszanak a károsodás kialakulásában, amelyek súlyos szisztémás szövődményekhez és a szerv maradandó károsodásához vezethetnek. Mindezek alapján az I-R károsodások mérséklése, jelentős klinikai relevanciája miatt jelenleg is számos kutatás célpontját képezi.

\section{Az ischaemiás-reperfúziós károsodás}

Az ischaemia során a szövetek számára elérhető oxigénkínálat, illetve oxigénigényük közötti egyensúly megbomlása jön létre, akár az előbbi komponens csökkenése, akár az utóbbi emelkedése folytán. Fellépését követően kompenzáló folyamatok (fokozott hemoglobindeszaturáció, kapilláris „besorozás”) lépnek érvénybe [1], azonban ezek kimerülésével kialakul a szövetek ischaemiás sérülése, amelynek legfőbb aspektusai a sejtmetabolizmus átrendeződése, az intracelluláris (ic.) energetikai krízis és acidózis, ionpumpa-diszfunkció és következményes ioneloszlási zavar, illetve ic. és intramitokondriális $\mathrm{Ca}^{2+}$-akkumuláció, amelyek végső soron a sejt halálához vezetnek [2]. A sejtek túlélésének feltétele az oxigén visszatértével járó reperfúzió, amely azonban paradox módon további, potenciálisan súlyos károsodások kiindulópontja lehet. A reperfúziós károsodás létrejöttében meghatározó szerep jut a szabad gyökök nagy mennyiségû képződésének, a diszfunkcionális nitrogén-monoxid(NO-) termelésnek, a párhuzamosan fellépő mikrocirkulációs elégtelenségnek („no-reflow”, „reflow paradox”), valamint a sérült szövetek gyulladásos aktivációjának és az ezt követő, beáramló neutrophil granulocyták mediálta immunológiai károsodásnak [2]. A helyi sérülések fellépésén túl ugyanakkor a gyulladásos mediátorok, citokinek és szabad gyökök disszeminációjával szisztémás szövődmények is kialakulhatnak [3]. A gyulladásos egyensúlyban bekövetkező eltolódás (systemic inflammatory response syndrome - SIRS) gyakorta többszervi elégtelenséghez (multi organ dysfunction syndrome/ failure - MODS/MOF) vezet, annak kiugróan magas (60-100\%) mortalitásával [4].

Az ischaemiás-reperfúziós (I-R) károsodások felfoghatók úgy, mint egyfajta komplex oxidoreduktív stresszzavar [2]. Ennek keretében a szövetek számára az ischaemia egy reduktív, míg a reperfúzió egy súlyos oxidatív stresszt jelent. Ischaemiában a mitokondriumok légzési láncai - $\mathrm{O}_{2}$-szubsztrát hiányában - nem képesek a katabolizmus során nyert redukált $\mathrm{NADH}+\mathrm{H}^{+}$molekulák oxidációjára. Így a felszaporodó $\mathrm{NADH}+\mathrm{H}^{+}$révén egy jelentős ic. reduktív stressz alakul ki. Ezzel szemben a reperfúzió folyamata drámai oxidatív stresszt jelent a nagy mennyiségben szintetizálódó szabad gyökök révén, amelyek eredete eltérő. Egyfelől a sérült mitokondriumok légzési láncain fokozott ROS-szintézis történik. Másrészről a szabad gyökök egyik legfőbb forrása a xantinoxidáz enzim, amely az ischaemiás periódusban xantin-dehidrogenázból képződik egy $\mathrm{Ca}^{2+}$-dependens hasítás következtében [5]. Továbbá az aktivált makrofágok indukálható nitrogén-monoxid-szintáz (iNOS) enzimaktivitása, valamint a beáramló neutrophilgranulocyta-sejtek NADPH-oxidáz enzimaktivitása, a diszfunkcionális endothelialis NOS és az l-es típusú angiotenzinII-receptor révén szintén nagy mennyiségü reaktív gyök (ONOO ${ }^{-}$; ROS) képződik. A szabad gyökök $\left(\mathrm{O}^{2-}, \mathrm{H}_{2} \mathrm{O}_{2}\right.$, $\mathrm{HOCl}^{-}$stb.) képződése már az ischaemia során beindul alacsony intenzitással, azonban a reperfúzió során beáramló $\mathrm{O}_{2}$-molekulák következtében a fenti mechanizmusok révén szintetizált ROS-ek produkciója drámai mértékben, ugrásszerúen fokozódik (respiratory burst) [6]. Az említett folyamatok során szintetizálódó szabad gyökök direkt sejtkárosító hatással rendelkeznek jelentős adduktképzési hajlamuk révén, amely végső soron szerepet játszik a DNS- és a membránkötött fehérjék funkciójának károsodásában. Továbbá a szabad gyökök kifejezett proinflammatorikus hatással bírnak, amennyiben: (1) gyulladásosan aktiválják a beáramló leukocytákat, thrombocytákat és lokális endothelsejteket, így (2) fokozva azok interakcióit és a fehérvérsejtek extravasatióját, valamint (3) az aktivált lokális és beáramló fehérvérsejtek további, erős hatású citokinek (TNF- $\alpha$, IL-1 $\beta$, IL-6, IFN- $\gamma$, egyéb) forrásává válnak [7]; illetve (4) csökkentik az endothel nitrogén-monoxid- (NO-) termelését, amely perfúziós zavarokat generál, illetve fokozza a fenti sejtek gyulladásos interakcióit [8]. Mindezek értelmében tehát a nagy mennyiségben felszabaduló szabad gyökök multifaktoriális káros hatásukkal járulnak hozzá a reperfúziós károsodásokhoz $[9,10]$. A máj I-R sérülésének specifikus jellegzetességei terén a Rappaport-féle májacinus [11] jól magyarázza a zonálisan heterogén kifejlődésû I-R károsodásokat [12]. Továbbá, a máj - jellemzően kétfázisú - I-R károsodásában [13] a korai fázis dominánsan a reoxigenizáció kapcsán termelt ROS-eknek, valamint a Kupffer-sejtek aktivációjának tudható be. Ez utóbbi felelős a késői fázis létrejöttéért, amelyben a gyulladásosan aktivált, nagyszámban beáramló neutrophil granulocyták által kifejtett károsodás (NADPH-oxidáz, hidrolitikus enzimek) dominál [14]. A két fázis hatására együttesen jön létre a máj redox-homeosztázisának - irodalmilag elfogadott méréstechnikai paraméterekkel jellemezhető $[15,16,17,18,19]$ - károsodása.

\section{Kondicionáló eljárások és máj ischaemia- reperfúzió - állatkísérleteink tükrében}

A Murry és mtsai [20] által 1986-ban kardiológiai állatkísérlet keretében felfedezett, prekondicionálás mérséklő 
szerepét munkacsoportunk szintén vizsgálta kísérletesen létrehozott, eltérő időtartamú parciális patkánymáj I-R [21], valamint parciális máj I-R mellett párhuzamosan elvégzett intraoperatív radioterápia kapcsán [22]. Eredményeink szerint a prekondicionálás mindkét esetben képes volt mérsékelni a máj I-R károsodását. Kiemelendő a mindkét kísérlet során megfigyelt redox-homeosztázis megtartottsága (kemiluminometria, tiolcsoportok, $\mathrm{H}^{+}$ donorok, redukálóerő), amelyhez feltehetőleg tevékenyen hozzájárult a prekondicionálás első kísérletben igazolt mikrocirkulációt javító hatása, valamint a második kísérletben megfigyelt, radioterápia okozta sérülés mérséklő hatása [21, 22]. Przyklenk és munkatársainak [23] 1993-as, valamint Schmidt és munkatársainak [24] 2007-es, úttörő felfedezéseit követően a perkondicionáló kezelés tanulmányozásával laborunk is behatóan foglalkozott, mind annak háttérmechanizmusai [25], mind kísérletes vizsgálata kapcsán. Korábbi kísérletünkben elsőként igazoltuk a perkondicionáló kezelés hepatoprotektív szerepét, amely a redox-homeosztázis késői (6-24 órás) károsodásának mérséklődéséhez vezetett [26]. Ezt követő, szelektív denervációs kísérletünkben a perkondicionáló kezelés protektív hatásának neuralis komponensét vizsgáltuk, ahol az idegblokád alkalmazása a hepatoprotekció globális, szignifikáns csökkenését eredményezte. Bár a redox-homeosztázis tekintetében utóbbi igaz a szabadgyök-terhelés szempontjából, a denerváció nem szüntette meg az antioxidánsszintek javulását [27]. A - kardiológiai alkalmazása kapcsán inodilatátor hatású szerként ismert - levosimendan a klasszikus kémiai kondicionálószerek közé tartozik. Fő hatása - RISKaktivátor [28] és NO-felszabadító [29] hatása mellett a mitokondriális $\mathrm{K}^{+}{ }_{\mathrm{ATP}}$-csatorna nyitása, amely a mitokondrium integritásának, illetve a terminális oxidáció pontos múködésének megőrzéséhez vezet [30]. Ebbéli antiischaemiás, gyulladásgátló hatása saját kísérletünkben is igazolódott, ahol a „korai” (1-3 órás), illetve „késői”” (24 órás) preoperatív előkezelés a máj I-R károsodásának csökkenéséhez vezetett. Szembetűnő a levosimendan - kutatócsoportunk által kifejlesztett [31] - NAD-tetrazólium festéssel igazolt mitokondriumviabilitást megőrző hatása, amely áttételesen elképzelhető, hogy a mitokondriálisan létrejött szabadgyöktermelés csökkentésével vezetett a redoxpanel szignifikáns javulásához [32]. Szintén kémiai kondicionálószer az adenozin (illetve az inozin), amelynek dokumentált, receptoriális (dominánsan $\mathrm{A}_{2 \mathrm{~A}}$ ) receptoraktivációját, illetve ezt követő ic. kinázokat (RISK) aktiváló hatása mellett [33] újszerü, eddigiekben kevésbé ismert hatásmechanizmusaira derült fény laborunk kollaboráló kísérletében. A primer májrákból származó in vitro modellen történő kísérlet I-R szimulálását követően azonosította az adenozin védőhatásának hatásos koncentrációját [34]. Továbbá igazolást nyert, hogy az adenozin védőhatását legalábbis részben exogén energiaszubsztrát-funkciót betöltve fejti ki, mivel ic. bejutását követően, inozin intermedier metaboliton keresztül foszforilálódik AMP-vé, majd ADP-vé [34]. Szoros értelemben véve nem kondicionálószer a glutamin, azonban számos jótékony hatásánál fogva régóta ismeretes pozitív hatása számos katabolikus állapot kapcsán [35]. İgy preoperatív ( „későbbi”: 3 óra; „korábbi”: 24 óra) alkalmazásának lehetőségét kutatócsoportunk máj I-R károsodása kapcsán vizsgálta $[36,37]$. A kezelés szignifikánsan csökkentette a máj I-R károsodását, amelynek hátterében állhat egyfelől a nekrotikus folyamatok helyett az apoptózis - TUNEL-festéssel és kaszpáz-3 immunhisztokémiával igazolt - serkentése. Másfelől a glutamin szignifikánsan javította a májredoxpanelt - a „korábbi” csoportban minden aspektusában, míg a „későbbi” csoportban csak a szabadgyökterhelést és tiolcsoportok koncentrációját - antioxidáns tulajdonságú GSH-prekurzor tulajdonságának fényében [38]. A - fiziológiásan DNS-hibajavító funkciót betöltő - poli-ADP-ribóz-polimeráz (PARP) enzim túlmúködése a sejt energetikai kríziséhez, ezáltal nekrózishoz vezet [39]. Így az enzimmúködés gátlása a nekrózis elkerülésével és az apoptotikus folyamatok dominálásával a gyulladás csökkenéséhez vezethet [40], amelyet a korábbi, vitatott eredmények közül több megerősít [41]. Munkacsoportunk ezzel egybehangzó következtetésekre jutott saját, PJ-34 PARP-inhibitor-kezelést alkalmazó kísérletében, ahol a máj I-R károsodásának mérséklődésével párhuzamosan szignifikánsan magasabb TUNEL-pozitivitás, a nekrózis hiánya és a máj szabadgyök-terhelésének csökkenése igazolódott [42].

\section{Következtetés}

Az ismertetett kondicionálóeljárások saját eredményeink függvényében képesek voltak modalitásuk, támadáspontjaik és hatáserősségük tekintetében eltérő módon és mértékben az I-R kapcsán kialakuló májkárosodások csökkentésére és a redox-homeosztázis megőrzésére.

Anyagi támogatás: A közlemény az MTA Bolyai János Kutatási Ösztöndíj támogatásával készült.

A szerző a cikk végleges változatát elolvasta és jóváhagyta.

Érdekeltségek: A szerzőnek nincsenek érdekeltségei.

\section{Irodalom}

[1] Bulkley, G. B., Kvietys, P. R.; Parks, D. A., et al.: Relationship of blood flow and oxygen consumption to ischemic injury in the canine small intestine. Gastroenterology, 1985, 89(4), 852-857.

[2] Anaya-Prado, R., Toledo-Pereyra, L. H.: The molecular events underlying ischemia/reperfusion injury. Transplant. Proc., 2002, 34(7), 2518-2519.

[3] Blaisdell, F. W.: The pathophysiology of skeletal muscle ischemia and the reperfusion syndrome: a review. Cardiovasc. Surg., 2002, $10(6), 620-630$.

[4] Biffl, W. L., Moore, E. E.: Splanchnic ischaemia/reperfusion and multiple organ failure. Br. J. Anaesth., 1996, 77(1), 59-70. 
[5] Parks, D. A., Williams, T. K., Beckman, J. S.: Conversion of xanthine dehydrogenase to oxidase in ischemic rat intestine: a reevaluation. Am. J. Physiol., 1988, 254(5), G768-G774.

[6] Halliwell, B., Gutteridge, J. M. (eds.): Free radicals in biology and medicine. 3rd ed. Oxford University Press, Oxford, 1999.

[7] Ogawa, K., Kondo T., Tamura, T., et al.: Influence of Kupffer cells and platelets on ischemia-reperfusion injury in mild steatotic liver. World J. Gastroenterol., 2013, 19(9), 1396-1404.

[8] Abu-Amara, M., Yang, S. Y., Seifalian, A., et al.: The nitric oxide pathway - evidence and mechanisms for protection against liver ischaemia reperfusion injury. Liver Int., 2012, 32(4), 531-543.

[9] Halliwell, B., Gutteridge, J. M. (eds.): Free radicals in biology and medicine. 2nd ed. Clarendon Press, Oxford, 1989.

[10] Ferrari, R., Ceconi, C., Curello, S., et al.: Role of oxygen free radicals in ischemic and reperfused myocardium. Am. J. Clin. Nutr., 1991, 53(1 Suppl.), 215S-222S.

[11] Rappaport, A. M.: Hepatic blood flow: morphologic aspects and physiologic regulation. Int. Rev. Physiol., 1980, 21, 1-63.

[12] Szijártó, A.: Increased ischemic tolerance in liver surgery. [Az ischaema-tolerancia növelésének lehetőségei a májsebészetben.] Magy. Seb., 2008, 61(3), 128-135. [Hungarian]

[13] Menger, M. D., Richter, S., Yamauchi, J., et al.: Role of microcirculation in hepatic ischemia/reperfusion injury. Hepatogastro enterology, 1999, 46(Suppl. 2), 1452-1457.

[14] Jaeschke, H., Farhood, A.: Neutrophil and Kupffer cell-induced oxidant stress and ischemia-reperfusion injury in rat liver. Am. J. Physiol., 1991, 260(3), G355-G362.

[15] Blázovics, A., Kovács, A., Lugasi, A., et al.: Antioxidant defense in erythrocytes and plasma of patients with active and quiescent Crohn disease and ulcerative colitis: a chemiluminescent study. Clin. Chem., 1999, 45(6), 895-896.

[16] Blois, M. S.: Antioxidant determination by the use of stable free radicals. Nature, 1958, 181(4617), 1999-2000.

[17] Oyaizu, M.: Studies on products of browning reaction - antioxidative activities of products of browning reaction prepared from glucosamine. Eiyogaku zasshi = Japanese journal of nutrition, 1986

[18] Sedlak, J., Lindsay, R. H.: Estimation of total, protein-bound, and nonprotein sulfhydryl groups in tissue with Ellman's reagent. Anal. Biochem., 1968, 25(1), 192-205.

[19] Taccone-Gallucci, M., Lubrano, R., Meloni, C., et al.: Malonyldialdehyde content of cell membranes is the most important marker of oxidative stress in haemodialysis patients. Nephrol. Dial. Transplant., 1998, 13(10), 2711-2712.

[20] Murry, C. E., Jennings, R. B., Reimer, K. A.: Preconditioning with ischemia: a delay of lethal cell injury in ischemic myocardium. Circulation, 1986, 74(5), 1124-1136.

[21] Szijarto, A., Hahn, O., Lotz, G., et al.: Effect of ischemic preconditioning on rat liver microcirculation monitored with laser Doppler flowmetry. J. Surg. Res., 2006, 131(1), 150-157.

[22] Hahn, O., Szijárto, A., Lotz, G., et al.: The effect of ischemic preconditioning prior to intraoperative radiotherapy on ischemic and on reperfused rat liver. J. Surg. Res., 2007, 142(1), 32-44.

[23] Przyklenk, K., Bauer, B., Ovize, M., et al.: Regional ischemic 'preconditioning' protects remote virgin myocardium from subsequent sustained coronary occlusion. Circulation, 1993, 87(3), 893-899.

[24] Schmidt, M. R., Smerup, M., Konstantinov, I. E., et al.: Intermittent peripheral tissue ischemia during coronary ischemia reduces myocardial infarction through a $\mathrm{K}_{\mathrm{ATP}}$-dependent mechanism: first demonstration of remote ischemic perconditioning. Am. J. Physiol. Heart Circ. Physiol., 2007, 292(4), H1883-H1890.

[25] Szijártó, A., Czigány, Z., Turóczi, Z., et al.: Remote ischemic perconditioning - a simple, low-risk method to decrease ischemic reperfusion injury: models, protocols and mechanistic back ground. A review. J. Surg. Res., 2012, 178(2), 797-806.

[26] Czigány, Z., Turóczi, Z., Ónody, P., et al.: Remote ischemic per conditioning protects the liver from ischemia-reperfusion injury. J. Surg. Res., 2013, 185(2), 605-613.

[27] Czigany, Z., Turóczi, Z., Kleiner, D., et al.: Neural elements behind the hepatoprotection of remote perconditioning. J. Surg. Res., 2015, 193(2), 642-651.

[28] Soeding, P. F., Crack, P. J., Wright, C. E., et al.: Levosimendan preserves the contractile responsiveness of hypoxic human myocardium via mitochondrial $\mathrm{K}_{\mathrm{ATP}}$ channel and potential pERK 1/2 activation. Eur. J. Pharmacol., 2011, 655(1-3), 59-66.

[29] Grossini, E., Molinari, C., Caimmi, P. P., et al.: Levosimendan induces NO production through p38 MAPK, ERK and Akt in porcine coronary endothelial cells: role for mitochondrial $\mathrm{K}_{\mathrm{ATP}}$ channel. Br. J. Pharmacol., 2009, 156(2), 250-261.

[30] Pollesello, P., Papp, Z.: The cardioprotective effects of levosimendan: preclinical and clinical evidence. J. Cardiovasc. Pharmacol., 2007, 50(3), 257-263.

[31] Turóczi, Z., Arányi, P., Lukáts, A., et al.: Muscle fiber viability, a novel method for the fast detection of ischemic muscle injury in rats. PLoS ONE, 2014, $9(1)$, e84783.

[32] Onody, P., Stangl, R., Fulop, A., et al.: Levosimendan: a cardiovascular drug to prevent liver ischemia-reperfusion injury? PLoS ONE, 2013, 8(9), e73758.

[33] Gomez, G., Sitkovsky, M. V.: Differential requirement for A2a and A3 adenosine receptors for the protective effect of inosine in vivo. Blood, 2003, 102(13), 4472-4478.

[34] Modis, K., Gero, D., Stangl, R., et al.: Adenosine and inosine exert cytoprotective effects in an in vitro model of liver ischemiareperfusion injury. Int. J. Mol. Med., 2013, 31(2), 437-446.

[35] Lochs, H., Dejong, C., Hammarqvist, F., et al.: ESPEN guidelines on enteral nutrition: Gastroenterology. Clin. Nutr., 2006, 25(2), 260-274.

[36] Stangl, R., Szijarto, A., Onody, P. et al.: Reduction of liver ischemia-reperfusion injury via glutamine pretreatment. J. Surg. Res., 2011, 166(1), 95-103.

[37] Szijarto, A., Hahn, O., Batmunkh, E., et al.: Short-term alanylglutamine dipeptide pretreatment in liver ischemia-reperfusion model: effects on microcirculation and antioxidant status in rats. Clin. Nutr., 2007, 26(5), 640-648.

[38] Preiser, J. C., Wernerman, J.: Glutamine, a life-saving nutrient, but why? Crit. Care Med., 2003, 31(10), 2555-2556.

[39] Berger, S. J., Sudar, D. C., Berger, N. A.: Metabolic consequences of DNA damage: DNA damage induces alterations in glucose metabolism by activation of poly (ADP-ribose) polymerase. Biochem. Biophys. Res. Commun., 1986, 134(1), 227-232.

[40] Cuzzocrea, S., Thiemermann, C., Salvemini, D.: Potential therapeutic effect of antioxidant therapy in shock and inflammation. Curr. Med. Chem., 2004, 11(9), 1147-1162.

[41] Khandoga, A., Biberthaler, P., Enders, G., et al.: 5-aminoisoquinolinone, a novel inhibitor of poly(adenosine disphosphate-ribose) polymerase, reduces microvascular liver injury but not mortality rate after hepatic ischemia-reperfusion. Crit. Care Med., 2004, 32(2), 472-477.

[42] Szijártó, A., Batmunkh, E., Hahn, O., et al.: Effect of PJ-34 PARP-inhibitor on rat liver microcirculation and antioxidant status. J. Surg. Res., 142(1), 72-80.

(Szijártó Attila dr., Budapest, Üllői út 78., 1082 e-mail: szijartoattila@gmail.com) 